\title{
USE IR-SPECTROSCOPY IN TREATMENT ONCOLOGICAL PATIENTS WITH BONE METASTASES BY ${ }^{153} \mathrm{Sm}$-OXABIFOR
}

\author{
N.P.Dikiy ${ }^{1 *}$ N.V.Krasnoselsky ${ }^{2}$, E.P.Bereznyak ${ }^{1}$, \\ A. V. Grushka ${ }^{2}$, E.P.Medvedeva ${ }^{1}$ \\ ${ }^{1}$ National Science Center "Kharkiv Institute of Physics and Technology", 61108 Kharkiv, Ukraine; \\ ${ }^{2}$ S.P. Grigoriev Institute of Medical Radiology, 61024 Kharkiv, Ukraine
}

(Received September 30, 2019)

\begin{abstract}
Using infrared spectroscopy, we studied the character of intermolecular interactions in the samples blood plasma of oncological patients with bone metastases in the treatment of their modern $\beta$-emitter ${ }^{153} \mathrm{Sm}$-oxabifor. The therapeutic dose of the ${ }^{153} \mathrm{Sm}$-oxabifor was $1.0 \mathrm{mCi} / \mathrm{kg}$ of the patient's body weight. Analysis of the IR-spectra showed that already after the first course of palliative radionuclide therapy there is a tendency to balance the products of free radical nature and antioxidants, which indicates the effectiveness of the treatment. Molecular changes in the blood plasma of cancer patients with bone metastases registered using infrared spectroscopy are specific during palliative therapy.
\end{abstract}

PACS: $87.53 . \mathrm{Jw}$

\section{INTRODUCTION}

Currently, osteotropic isotopes of ${ }^{153} \mathrm{Sm},{ }^{186-188} \mathrm{Rn}$, ${ }^{177} \mathrm{Lu}$, and others are used in the treatment of bone metastatic disease [1]. All radioisotopes differ in their physical properties, but it has similar clinical efficacy $[1,2]$.

The ${ }^{153} \mathrm{Sm}$ radionuclide has a half-life of 46.2 hours, emits particles with energies of 650,720 , and $820 \mathrm{keV}$ with outputs of 20,40 , and $60 \%$, respectively, which is sufficient for local exposure of the local zone.

$\gamma$-quanta with energies of 69.7 and $106 \mathrm{keV}$ and outputs of 5.4 and $28 \%$, respectively, make it possible to record the accumulation and distribution of the radionuclide using a gamma camera. The ${ }^{153} \mathrm{Sm}$-oxabifor radionuclide has the most pronounced analgesic properties and minimum accompany effects. The advantages of ${ }^{153} \mathrm{Sm}$-oxabifor are the following indicators: high selective accumulation in the zone of metastases; rapid elimination from healthy tissue; relatively low toxicity of the drug; the possibility of scintigraphic assessment of the accumulation and distribution of the drug, etc. [3].

Cancer patients with bone metastases are one of the most severe categories of patients which require effective and well-planned palliative treatment using ${ }^{153} \mathrm{Sm}$-oxabifor. Metastases of the skeletal system often lead to the development of different complications such as hypercalcemia, bone pain, pathological fractures, deterioration of the general state and quality of life of patients. Therefore, the use of a multifactor approach in the treatment of this category of patients consists in finding the most appropriate individual methods of monitoring radiation loads on the bloodforming organs, taking into control their.

Hematologic complications can interfere with the continuation of anticancer treatment and lead to a decrease in the life duration of these patients. In some cases, it is necessary to conduct additional hemostimulating therapy.

Among other effects of ${ }^{153} \mathrm{Sm}$, its influence on the hematopoietic system of the bone marrow (granulocytes, platelets) is noted. Therefore, the study of the phase composition and peculiarities of the molecular structure of various organic and inorganic compounds of blood cells "before", "during treatment" and "after treatment" of ${ }^{153} \mathrm{Sm}$-oxabifor represents interest [4].

The purpose of this work was to study the characteristics of the infrared spectra of the blood of oncological patients with bone metastases with different primary localization of the tumor process, as well as to estimate of next injections of ${ }^{153} \mathrm{Sm}$-oxabifor in the course of palliative therapy.

\section{MATERIALS AND METHODS}

The object of the study was the blood of oncological patients with bone metastases with primary tumors of the mammary gland, prostate, and uterus. As a control, the blood of oncological patients which did not have bone metastases and which had not radionuclide therapy with ${ }^{153} \mathrm{Sm}$-oxabifor was used.

Treatment of these patients was carried out with the help of the drug ${ }^{153} \mathrm{Sm}$-oxabifor, manufactures of company "Radio preparation" Institute of nuclear physics AS of Uzbekistan (the registration certificate

\footnotetext{
*Corresponding author E-mail address: ndikiy@kipt.kharkov.ua
} 
N85, a series 026251114 , cleanliness $99.2 \%$, activity $2842.61 \mathrm{MBq}$, initial activity $8400 \mathrm{MBq}$ ). Content of impurity radionuclides was not more than $3 \cdot 10^{-3} \%$.

The recommendations of the European Association of Nuclear Medicine (EANM) regarding the use of ${ }^{153} \mathrm{Sm}$ [5] leave the problem of individual dosing for particular patients unresolved. Palliative doses of ${ }^{153} \mathrm{Sm}$ for effective therapy are up to $37 \mathrm{MBq} / \mathrm{kg}$ [6]. The direct therapeutic effect of radionuclide therapy of bone metastases is associated with the use of high activities up to $1110 \mathrm{MBq} / \mathrm{kg}$ [7].

${ }^{153} \mathrm{Sm}$-oxabifor was injected to patients intravenously. The calculation of the therapeutic dose of the drug was carried out at the rate of $1.0 \mathrm{mCi} / \mathrm{kg}$ of the patient's body weight.

The IR-spectra of plasma were recorded on an IKS-29 IR-spectrometer (LOMO) in the spectral range of $4200 \ldots 400^{-1} \mathrm{~cm}^{-1}$ (wavelength range from 2 to $25 \mu \mathrm{m}$ middle infrared region) [7-14]. Calibration was carried out on the spectrum of polystyrene with certain frequencies of absorption maxima. The amendment was $10^{-5} \mathrm{~cm}^{-1}$.

A drop of the plasma was placed between two round disks of $\mathrm{CaF}_{2}$ and installed in the measuring channel of the device. The same plates were installed in the reference channel but without liquid. The spectrum was recorded immediately after the sample was inserted and lasted 10 minutes. The temperature in the cell compartment was $25 \ldots 30^{\circ} \mathrm{C}$.

\section{RESULTS AND DISCUSSION}

Since the basis of the investigated plasma samples is water, the most intense and wide bands in the spectrum correspond to different types of oscillations of $\mathrm{H}_{2} \mathrm{O}$ molecules [15]:

1. Librational (Latin libration-swinging) $\mathrm{H}_{2} \mathrm{O}$ modes correspond to strong absorption in the range of $700 \ldots 600^{-1} \mathrm{~cm}^{-1}$.

2. A narrow intense band in the region of $1700 \mathrm{~cm}^{-1}$ is attributed to the deformation oscillations of $\mathrm{H}-\mathrm{O}-\mathrm{H}$ due to changes in the angles of valence bonds.

3 . The composite vibrational mode of the deformation and librational vibrations of $\mathrm{H}_{2} \mathrm{O}$ molecules lies in the range of $2150 \ldots 2200 \mathrm{~cm}^{-1}$.

4. The main band of valence vibrations due to changes in the bonds in the water molecule covers the spectral range of $3600 \ldots 3000 \mathrm{~cm}^{-1}$.

In addition, in the plasma, there are band spectra which corresponding to vibrations in the molecules of proteins and other compounds of blood [16-18]. The identification of these absorption bands is given in the Table.

Identification of bands in IR-spectra of oncological patient plasma, $\mathrm{cm}^{-1}$

\begin{tabular}{|c|c|c|c|c|c|}
\hline $\begin{array}{l}\text { Control, } \\
\text { patient C }\end{array}$ & $\begin{array}{l}\text { Patient } \mathrm{O}, \\
8-00\end{array}$ & $\begin{array}{l}\text { Patient } \mathrm{O}, \\
20-00\end{array}$ & $\begin{array}{l}\text { Patient B, } \\
8-00\end{array}$ & $\begin{array}{l}\text { Patient B, } \\
20-00\end{array}$ & labelling band \\
\hline $770 \ldots 630$ & $780 \ldots 620$ & $780 \ldots 620$ & $700 \ldots 660$ & 700 & librational modes $\mathrm{H}_{2} \mathrm{O}$ \\
\hline 810 & & & & & librational modes $\mathrm{H}_{2} \mathrm{O}$ \\
\hline \multirow[t]{2}{*}{1130} & & 1120 & & & $\begin{array}{l}\text { fluctuations of } \mathrm{C}-\mathrm{O} \text { and oxyhe- } \\
\text { moglobin }\end{array}$ \\
\hline & 1170 & 1160 & & & \\
\hline \multirow[t]{2}{*}{1250} & & 1235 & & & protein ring structure, amide \\
\hline & 1260 & 1280 & & & protein ring structure, amide \\
\hline \multirow[t]{2}{*}{1300} & & & & & protein ring structure, amide \\
\hline & 1400 & 1380 & 1400 & 1380 & $\begin{array}{l}\delta\left(\mathrm{CH}_{3}\right) \text { in the structure of lipids } \\
\text { and proteins }\end{array}$ \\
\hline \multirow[t]{2}{*}{1425} & & & & & $\begin{array}{l}\delta\left(\mathrm{CH}_{3}\right) \text { in the structure of lipids } \\
\text { and proteins }\end{array}$ \\
\hline & & 1440 & & 1440 & $\begin{array}{l}\delta\left(\mathrm{CH}_{3}\right) \text { in the structure of lipids } \\
\text { and proteins }\end{array}$ \\
\hline 1470 & & & & & $\begin{array}{l}\delta\left(\mathrm{CH}_{3}\right) \text { in the structure of lipids } \\
\text { and proteins }\end{array}$ \\
\hline 1570 & 1550 & 1550 & 1550 & 1550 & nitro compound $\left(-\mathrm{NO}_{2}\right)$ \\
\hline 1650 & 1630 & 1630 & 1630 & 1630 & deformation oscillations $\mathrm{H}-\mathrm{O}-\mathrm{H}$ \\
\hline 1680 & & & & & deformation oscillations $\mathrm{H}-\mathrm{O}-\mathrm{H}$ \\
\hline
\end{tabular}

The results of infrared spectroscopy of the plasma of patients $\mathrm{C}$ and $\mathrm{B}$ show the principal similarity of the spectra in the course of radionuclide therapy: the profiles of their spectra are almost identical in shape. In these spectra, wide absorption bands are observed in the region of 1400,1550 , and $1630 \mathrm{~cm}^{-1}$, which are associated with $\mathrm{COO}^{-}$, valent vibrations of $\nu(\mathrm{N}-$ $\mathrm{H})+\nu(\mathrm{C}-\mathrm{N})$ amide II and deformation vibrations of $\mathrm{H}-\mathrm{O}-\mathrm{H}$ and $\delta\left(\mathrm{CH}_{3}\right)$ in the structure of lipids and pro- teins, respectively. These groups of substances belong to the molecules of hydrocarbons, as well as to the complexes of hydrocarbons with proteins and lipids. The characteristic changes in plasma lipoproteins are often observed due to a decrease in $\alpha$-lipoproteins and an increase in $\beta$-proteids in oncological patients. When comparing the plasma spectra of patient $\mathrm{C}$ and $\mathrm{B}$, there is a slight shift of these bands to the right and a slight decrease in their intensity. 


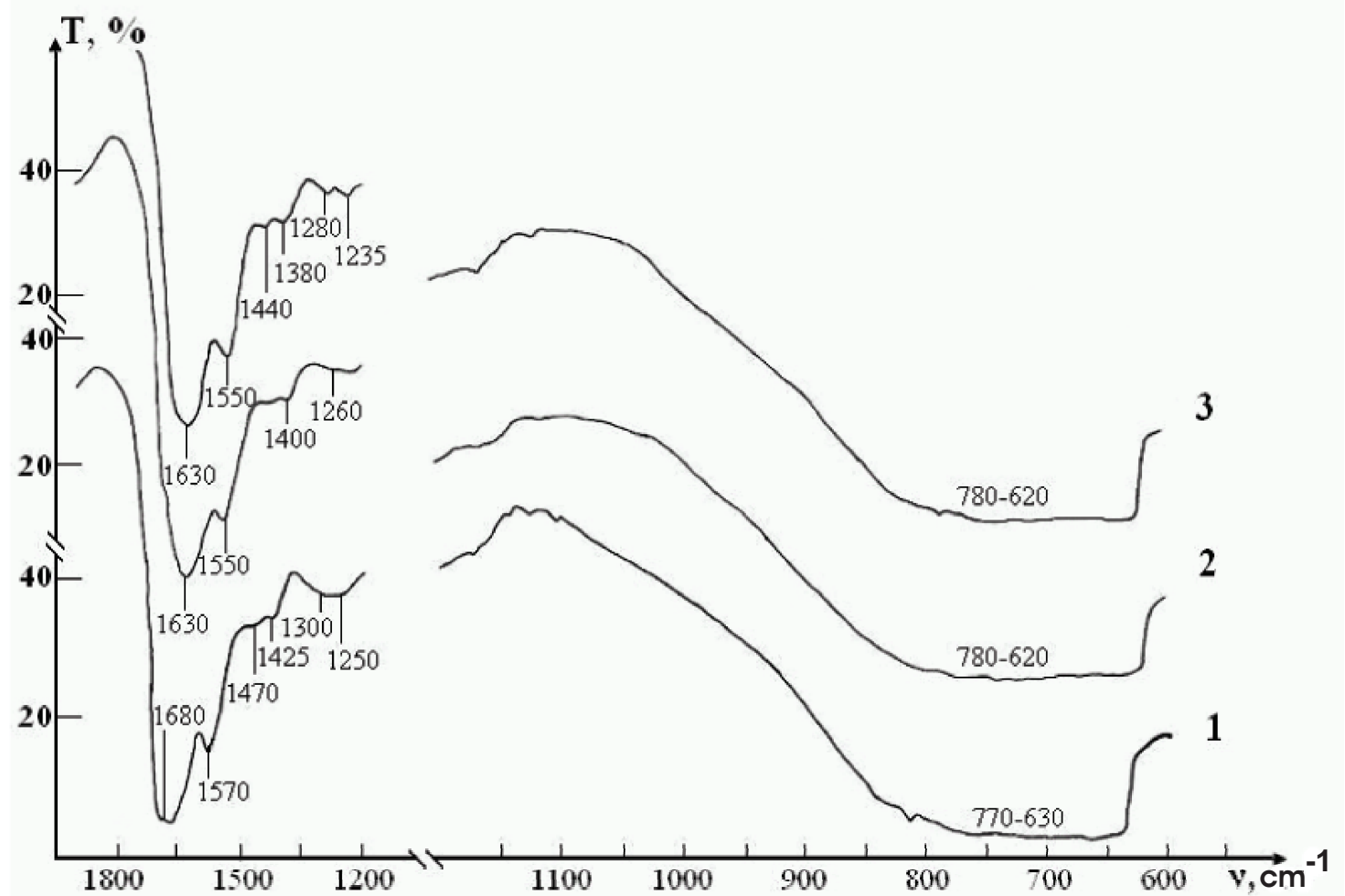

Fig.1.Absorption IR-spectrum: 1. The control, patient C; 2. Patient B, 8-00; 3. Patient B, 20-00

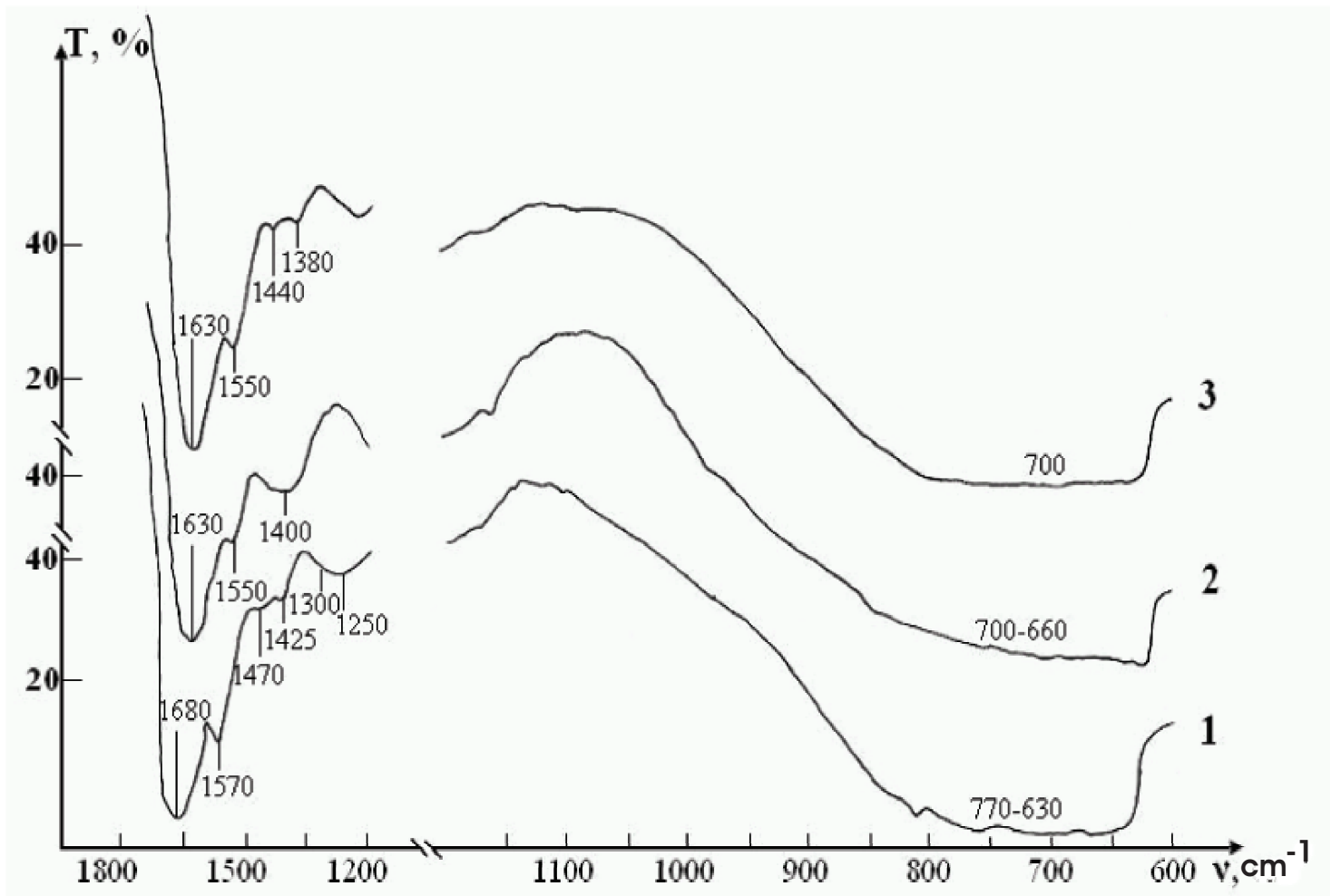

Fig.2.Absorption IR-spectrum: 1. The control, patient C; 2. Patient B, 8-00; 3. Patient B, 20-00

The presence of a pronounced band in the region of $1400 \mathrm{~cm}^{-1}$ in patients after the first injection of ${ }^{153} \mathrm{Sm}$-oxabifor in 8-00 indicates a higher intensity of free radical oxidation of fatty acids $\left(\mathrm{COO}^{-}\right)$. It is known [19] that, in the blood of patients with malig- nant neoplasms and metastases, there is an increased number of products of a bioactioxidant (BAO) nature, which are synthesized in the liver and transported to the tumor. The accumulation of BAO in tumor tissue leads to a decrease in the production 
of free radical (FR) products, which provides conditions for accelerated tumor growth. Analysis of the IR-spectra showed specific changes in the composition of the plasma of patients after the first course of injection of ${ }^{153} \mathrm{Sm}$-oxabifor. The intensity of the $1400 \mathrm{~cm}^{-1}$ band, which is associated with the appearance of products of free radical nature $\left(\mathrm{COO}^{-}\right)$, indicates a tendency to balance the products of $\mathrm{BAO}$ and FR and the development of an antitumor effect. On the basis of the obtained results, it is possible to evaluate the prospects and effectiveness of radionuclide therapy with ${ }^{153} \mathrm{Sm}$-oxabifor, determine the treatment regimen and the optimal dose and intervals between injection of the drug. An increase of FR in plasma is a kind of response of the body's regulatory systems that provide homeostasis.

The relationship of physicochemical parameters in the organism leads to the appearance of FR products with high reactivity, leads to changes in the strength of hydrophobic interactions and influence to proteinlipid bonds in the membranes of blood cells. In the context of this fact, there is a noticeable decrease in the intensity of the broadband in the region of $1400 \mathrm{~cm}^{-1}$ in patient $\mathrm{C}$ and $\mathrm{B}$ after the second injection of ${ }^{153} \mathrm{Sm}$-oxabifor in $20-00$ and the appearance of smoother bands in the region of 1380 and $1440 \mathrm{~cm}^{-1}$, which correspond to deformation fluctuations $\delta\left(\mathrm{CH}_{3}\right)$ in the structure of lipids and proteins. The basis of many pathological processes is precisely the change in the physical properties of the lipid layer of cell membranes and blood plasma lipoproteins. The lipid layer of the membrane performs the function of the structural basis, the matrix for protein enzyme molecules, ion channels, receptors and the function of a barrier for ions and hydrophilic molecules. These functions of the lipid layer of membranes are disturbed by pathological processes, which causes the development of some diseases and the complicates the course of others. The characteristic doublet of narrow and contiguous frequency intensity of bands $\nu_{1}, \nu_{2}\left(1380\right.$ and $\left.1440 \mathrm{~cm}^{-1}\right)$ after repeated injection of the ${ }^{153} \mathrm{Sm}$-oxabifor, apparently, may indicate the molecular mechanism of increasing the ion selective permeability for ions such as $\mathrm{H}^{+}\left(\right.$or $\left.\mathrm{OH}^{-}\right), \mathrm{K}^{+}, \mathrm{Ca}^{2+}$ and others. FR processes in cell membranes lead to serious changes in the physical properties of membranes, which underlie the functioning of membranes in various pathologies.

In the low-frequency, infrared region $(\nu \leq$ $\left.1150 \mathrm{~cm}^{-1}\right), 1120,1130 \mathrm{~cm}^{-1}$ absorption bands characteristic of blood cells are observed, which are associated with lattice vibrations of $\mathrm{C}-\mathrm{O}$ bonds and oxyhemoglobin $\left(\mathrm{HbO}_{2}\right)$. And if in patient $\mathrm{C}$ these bands are present, then in patient $\mathrm{B}$ its are completely absent. In the spectral region of $800 \ldots 600 \mathrm{~cm}^{-1}$, barely noticeable bands of $630,700,770$, and $780 \mathrm{~cm}^{-1}$ are observed, which are associated with vibrations of $\mathrm{Fe}-\mathrm{O}$ bonds which may be indirectly responsible for deformation fluctuations in the molecular structure of hemoglobin in patients in the course radionuclide therapy. Patient $\mathrm{C}$, who did not treatment by
${ }^{153} \mathrm{Sm}$-oxabifor, had more pronounced small peaks. The smoothing of small peaks in these areas may indicate a significant weakening of the intra- and intermolecular bonds in the structure of blood cells.

In the molecular vibrations of plasma, there are oxides of impurity metals which are characterized by the appearance of weakly intense peaks in the range from 700 to $810 \mathrm{~cm}^{-1}$.

Presence of a band of $1550 \mathrm{~cm}^{-1}$ testifies there is dioxide nitrogen $\left(\mathrm{NO}_{2}\right)$ in plasma of blood of patients after the first course of treatment ${ }^{153} \mathrm{Sm}$-oxabifor. According to modern data [20], the nitrogen of containing connections raises reactance lipidic peroxidase in lipoproteins low density, and also they are active immune troop mediator which takes part in tumor growth, it metastasis and in inhibition aggregations platelets.

The understanding of role $\mathrm{NO}$ and $\mathrm{NO}_{2}$ at the tumoral process is ambiguous. Production NO often connects with the intensity of a tumoral progression, degree malignancy, inactivation of $\mathrm{Fe}$, Cu-enzymes, and also inclusion of mechanisms apoptosis (the programmed destruction of cages). The strongly pronounced area of absorption of $1550 \mathrm{~cm}^{-1}$ after the first and second injection ${ }^{153} \mathrm{Sm}$-oxabifor testifies to increase in the maintenance of groups $\mathrm{NO}_{2}$ in plasma of blood of oncological patients. This fact proves there is a presence of strips of absorption in the field of 1380 and $1280 \mathrm{~cm}^{-1}$. In spite of the fact that NO is rather stable radical, but it appears insufficiently for oxidation biological targets especially at various pathological processes and in such cases oxidation lipoproteins take part. In this process take part dioxide nitrogen $\mathrm{NO}_{2}$ - and decomposition products NO:

$$
\mathrm{H}_{2} \mathrm{O}_{2}+\mathrm{NO}_{2}{ }^{-}+\mathrm{H} \rightarrow \mathrm{NO}_{2}{ }^{\circ}+\mathrm{HO}^{-}+\mathrm{H}_{2} \mathrm{O} \text {. }
$$

It is necessary to notice, that the described cascade of interactions is extremely important, but demands further research and the analysis.

The patient $\mathrm{C}$ which did not receive treatment ${ }^{153} \mathrm{Sm}$-oxabifor, bands of absorption of 1550,1380 , and $1280 \mathrm{~cm}^{-1}$ are absent (1), but there is a band of absorption in the field of $805 \mathrm{~cm}^{-1}$ which associates with $\nu(\mathrm{NO})$, valency, and bands 1425, 1470, 1570, $1680 \mathrm{~cm}^{-1}\left(\mathrm{CH}_{2}\right.$ (lipoproteins), $\mathrm{NH}+\mathrm{C}-\mathrm{N}$ (proteins), $=+N H$ (amide I), accordingly.

Thus, the analysis of IR-spectra has shown, that method IR-spectrometry can be used as an independent method which gives the chance to watch the efficiency of treatment of bone metastases ${ }^{153} \mathrm{Sm}$-oxabifor at level molecular structures of cell plasma of blood. The received results are the continuation of researches in area radionuclides therapies of bone metastases with use of ${ }^{153} \mathrm{Sm}$-oxabifor $[21,22]$.

\section{CONCLUSIONS}

1. The method of IR spectroscopy was used for the analysis of the phase composition, molecular structure and character of lattice vibrations of molecular bonds of plasma of oncological patients with bone metastases with different primary localization 
of the tumor process "before", "during treatment" and "after treatment" by ${ }^{153} \mathrm{Sm}$-oxabifor.

2. Changes of characteristic of blood plasma spectra of oncological patients with bone metastases have both similarity and specificity, which is reflected in the appearance of an intense band of $1400 \mathrm{~cm}^{-1}$, which is associated with the appearance of products of free radical nature $\left(\mathrm{COO}^{-}\right)$after the first course (8-00 ) treatment by ${ }^{153} \mathrm{Sm}$-oxabifor. This indicates a trend towards balancing the products of BAO and FR.

3. After the second course (20-00) of treatment with ${ }^{153} \mathrm{Sm}$-oxabifor there is a noticeable decrease in the intensity of the broadband in the region of $1400 \mathrm{~cm}^{-1}$ and the appearance of smoother bands in the region of 1380 and $1440 \mathrm{~cm}^{-1}$, which correspond to the deformation vibrations of $\delta\left(\mathrm{CH}_{3}\right)$ in the structure of lipids and proteins.

4. Features of IR-spectra of plasma of blood of oncological patients by treatment ${ }^{153} \mathrm{Sm}$-oxabifor, have shown presence of bands of absorption of $1550 \mathrm{~cm}^{-1}$, 1380 and $1280 \mathrm{~cm}^{-1}$ which associate with group $\mathrm{NO}_{2}$ in plasma of blood and absence of these bands of absorption at the patient who had not pass a course radionuclides therapies.

5 . In the low-frequency infrared region $(\nu \leq$ $1150 \mathrm{~cm}^{-1}$ ), absorption bands characteristic of blood cells are observed at $1120,1130 \mathrm{~cm}^{-1}$, which are associated with molecular vibrations of $\mathrm{C}-\mathrm{O}$ bonds and oxyhemoglobin $\left(\mathrm{HbO}_{2}\right)$, as well as the presence of a band $1550 \mathrm{~cm}^{-1}$, which indicates the content of $\mathrm{NO}_{2}$ in the plasma of patients.

6. Analysis of the IR-spectra of blood plasma showed a specific change in the molecular composition of blood plasma of oncological patients with bone metastases in the course treatment by ${ }^{153} \mathrm{Sm}$-oxabifor relative to an oncological patient who did not undergo by palliative radionuclide treatment.

\section{References}

1. A.N. Serafini. Therapy of metastatic bone pain // J. Nucl. Med. 2001, v.42(6), p.895-906.

2. N. Randit-Taskar, M. Batraki, C.R. Divgi. Radiopharmaceutical therapy for pfllftion of bone pain from osseous metastases // J. Nucl. Med. 2004, v.45(8), p.1358-1365.

3. O.I. Solodyannikova, V.V.Danilenko, et al. Samarium-153 oxabifor in the complex therapy of metastatic bone lesion // Ukrainian journal of radiology. 2014, vol.XXII, p.109-117.

4. V. Lewingtone. Cancer therapy using boneseeking isotopes // Phys. Med. Biol. 1996, v.4, p.2027-2042.

5. C. Hindorf, G. Glatting, C. Chiesa, et al. EANM Dosimetry Committee guidelines for bone marrow and whole-body dosimetry // Eur. J. Nucl. Med. Mol. Imaging. 2010, v.37, N.6, p.1238-1250.
6. K. Liepe. A comparative study of 188Re-HEDP, 186Re-HEDP, 153Sm-EDTMP and 89Sr in the treatment of painful skeletal metastases // Nucl. Med. Commun. 2007, v.28, v.8, p.623-630.

7. V.P. Verbalovich. Infrared spectroscopy of biological membranes Science. Alma-Ata, Kazakh SSR, 1977, $127 \mathrm{p}$.

8. L.A. Kozitsina, N.B. Kupletskaya. The use of $U V$, $I R$ and NMR spectroscopy in organic chemistry. Moscow, 1971, $213 \mathrm{p}$.

9. A. Cross. Introduction to practical infrared spectroscopy. Moscow: "Publishing House of Foreign Literature", 1961, 110 p.

10. A.A. Babushkin, P.A. Bazhulin, F.A. Korolev, et al. Spectral analysis methods. Moscow: "Publishing house of the Moscow University", 1962, 509 p.

11. L.A. Mushrooms. Introduction to the theory and calculation of the vibrational spectra of polyatomic molecules/ Ed. LSU, 1965, $134 \mathrm{p}$.

12. I. Kesler. Methods of infrared spectroscopy in chemical analysis, Moscow: "Mir", 1964, 257 p.

13. L.Yu. Bellamy. New data on the IR spectra of complex molecules. Moscow: "Mir", 1971, 230 p.

14. K. Nakanishi. Infrared Spectra and the Structure of Organic Compounds. Moscow: "Mir", 1965, $265 \mathrm{p}$.

15. V.F. Myshkin. The structure and properties of water // The scientific journal of KubSAU. 2012, v.81(07), p.1-12.

16. M.I. Voevoda, M.V. Kruchinina, S.E. Peltek, et al. The use of optical methods of blood analysis in the diagnosis of the stage of the disease in diffuse pathology of the liver // Archive of internal medicine. 2012, v.4(6), p.46-54.

17. M. Gutu, M. Avadanel, M. Marinca, et al. Exploratory Infrared Spectroscopy study of erythrocytes in cancer chemotherapy // Rev. Roum. Chim. 2017, v.62(2), p.181-190.

18. S.I. Turgunbaeva. Infrared Spectroscopy of Biological Membranes // Medicine and Ecology. 2005, v.1, p.71-73.

19. E.B. Burlakova,

A.V.Alesenko, E.M. Molochkina, et al. Bioantioxidants in radiation damage and malignant growth. Moscow: "Science", 1975, 211 p.

20. J.Byun, D.M. Mueller, J.S. Fabjan, et al. Nitrogen dioxide radical generated by the myeloperoxidase-hydrogen peroxide-nitrite system promotes lipid peroxidation of low density lipoprotein // FCEBS Letter. 1999, v.455, p.243246. 
21. N.P. Dikiy, A.V. Grushka, N.V.Krasnoselsky, et al. Contents of ${ }^{153} \mathrm{Sm}$-oxabifor in the blood of cancer patients during the treatment of bone metastases // Ukr. radiol. magazine. 2015,
v.XXIII, iss.2, p.196-197 (in Russian).

22. N.P. Dikiy, Yu.V. Lyashko, E.P. Medvedeva, et al. Kinetics of ${ }^{153} \mathrm{Sm}$ oxabifor for bone metastasis // PAST. 2015, v.97, N3, p.73-75.

\title{
ИСПОЛЬЗОВАНИЕ ИК-СПЕКТРОСКОПИИ ПРИ ЛЕЧЕНИИ КОСТНЫХ МЕТАСТАЗОВ ${ }^{153} \mathrm{Sm}$ ОКСАБИФОРОМ
}

\author{
Н. П. Дикий, Н. В. Красносельский, Е. П. Березняк, А. В. Грушка, Е. П. Медведева
}

Методом ИК-спектроскопии изучен характер межмолекулярных взаимодействий в образцах плазмы крови онкологических больных с костными метастазами в процессе лечения их современным $\beta$ излучателем ${ }^{153} \mathrm{Sm}$-оксабифором. Лечебная доза препарата ${ }^{153} \mathrm{Sm}$-оксабифора составляла 1,0 мКи $/$ кг массы тела больного. Анализ ИК-спектров показал, что уже после первого курса паллиативной радионуклидной терапии отмечается тенденция к сбалансированию продуктов свободнорадикальной природы и антиоксидантов, что свидетельствует об эффективности проводимого лечения. Зарегистрированные с помощью метода ИК-спектроскопии молекулярные изменения в плазме крови онкологических больных с костными метастазами являются специфическими в ходе проведения паллиативной терапии.

\section{ВИКОРИСТАННЯ ІЧ-СПЕКТРОСКОПІЇ ДЛЯ ЛІКУВАННЯ КІСТКОВИХ МЕТАСТАЗІВ ${ }^{153} \mathrm{Sm}$ ОКСАБІФОРОМ}

\section{М. П. Дикий, М. В. Красноселъсъкий, О. П. Березняк, А. В. Грушка, О. П. Медведєва}

Методом ІЧ-спектроскопії вивчено характер міжмолекулярних взаємодій в зразках плазми крові онкологічних хворих з кістковими метастазами в процесі лікування їх сучасним $\beta$-випромінювачем ${ }^{153} \mathrm{Sm}$ оксабіфором. Лікувальна доза препарату ${ }^{153} \mathrm{Sm}$-оксабіфору становила $1,0 \mathrm{mKi} /$ кг маси тіла хворого. Аналіз ІЧ-спектрів показав, що вже після першого курсу паліативної радіонуклідної терапії відзначається тенденція до збалансування продуктів вільнорадикальної природи і антиоксидантів, що свідчить про ефективність проведеного лікування. Зареєстровані за допомогою методу ІЧ-спектроскопії молекулярні зміни в плазмі крові онкологічних хворих з кістковими метастазами є специфічними під час проведення паліативної терапії. 